\title{
Modeling the Demand for Islamic Microfinance Services: An Application of PLS-SEM Approach
}

\author{
Mohamed Asmy Bin Mohd Thas Thaker ${ }^{1 *}$, Salina Kassim², Md Fouad Bin Amin ${ }^{3}$, \\ Marhanum Che Mohd Salleh", Nadhrah Othman' ${ }^{5}$, Siti Nadhirah Kassim 6 \\ *) Corresponding email: asmy@iium.edu.my
}

Article History

Received: May 20 ${ }^{\text {th }}, 2021$

Revised: June $17^{\text {th }}, 2021$

Accepted: November 29th 2021

\begin{abstract}
The access to capital is very crucial for ensuring the financial sustainability of microfinance clients. It is also equally important to determine the demand for microfinance services among the clients. This study aims to identify the factors affecting the demand for Islamic microfinance (ISMF) services among the women microentrepreneurs in Malaysia. This study has collected a total of 250 samples from the field survey on women micro-entrepreneurs who are also the clients of Amanah Ikhtiar Malaysia (AIM). In addition, Partial Least Squares (PLS) method used to identify the potential factors (4As) i.e., affordability, accessibility, adequacy and awareness affecting the demand for ISMF. The results show that only "accessibility" has significant and positive relation with the demand for IsMF. Besides, the measurements items of accessibility such as distance of ISMF institution, collateral requirement, guarantor requirement, application procedure and process, repayment method, service efficiency, advise and consultation, and number of IsMF centers are the key factors affecting the demand for ISMF services in Malaysia. This paper provides some insights for the policy makers of Islamic microfinance and recommends that ISMF providers should take accessibility factor into greater consideration for the economic upliftment of women in microenterprises in Malaysia.
\end{abstract}

Keywords: Islamic microfinance; Women; Amanah Ikthiar Malaysia; 4As

JEL Classification: C83; D02; G21; G23

Type of paper: Research Paper

@ IJIEF 2022 published by Universitas Muhammadiyah Yogyakarta, Indonesia

DOI:

https://doi.org/10.18196/ijief.v5i1.11776

\section{Web:}

https://journal.umy.ac.id/index.php/ijief/article/view/11776

\section{Citation:}

Thaker, M. A. M., Kassim, S., Amin, M. F. B., Salleh, M. C. M., Othman, N., \& Kassim, S. N. (2022) Modeling the demand for Islamic microfinance services: An application of PLS-SEM approach. International Journal of Islamic Economics and Finance (IJIEF), 5(1), 89-106. DOI: https://doi.org/10.18196/ijief.v5i1.11776.

\footnotetext{
${ }^{1}$ Associate Professor, Department of Economics, International Islamic University Malaysia, Malaysia

2 Institute of Islamic Banking and Finance, International Islamic University Malaysia, Malaysia

${ }^{3}$ Department of Economics, King Saud University, Saudi Arabia

${ }^{4}$ Department of Finance, International Islamic University Malaysia, Malaysia

${ }^{5}$ Institute of Islamic Banking and Finance, International Islamic University Malaysia, Malaysia

${ }^{6}$ Institute of Islamic Banking and Finance, International Islamic University Malaysia, Malaysia
} 
Thaker, Kassim, Amin, Salleh, Othman, \& Kassim $\mid$ Modeling the Demand for Islamic Microfinance Services: An Application of PLS-SEM Approach

\section{Introduction}

\subsection{Background}

Over the last few decades, the most widely discussed topic across the globe is on the concept of poverty alleviation. There are numerous approaches and tools supported by the government and non-government organizations in least developed and developing countries for poverty alleviation and economic well-being of the underprivileged group who are excluded from the conventional financial services. With the unique idea of poverty alleviation, Dr. M. Yunus won the noble prize in 2006 to support the poor through microcredit facility. Later on, the concept of micro-credit has expanded to microfinance covering a wide range of financial services such saving and insurance. The main goal of establishing microfinance institutions (MFIs) is to enhance the accessibility of microfinance products and services to the poor who become the entrepreneurs. The MFIs help the clients to strengthen their entrepreneurships, awareness and skills.

Since poverty alleviation is one of the biggest global concerns and an essential requirement for sustainable development, several efforts have been undertaken to address this issue with the help of education, medical care, economic development via microfinance services. As a factor of production, capital is considered an indispensable condition for economic growth. Microfinance services play a pivotal role and appear as an effective tool of improving the economic conditions of the poor and low-income group (Khandker, 2003; Gertler et al., 2003, and Park \& Ren, 2001).

In Malaysia, the number of microenterprises has increased significantly in various sectors including, food, craft, textile, and agriculture, which are mainly contributed by the microfinance services. Indeed, microenterprises has become one of the alternatives sources to generate income, but microentrepreneurs require small start-up capital, few workers, and good management system. More specifically, the number of women involved in microenterprises have increased remarkably across developing and least developed countries and Malaysia is not an exception where many women become economically self-reliant, promising micro-entrepreneurs and outperforming their male counterpart.

Malaysian government established Amanah Ikhtiar Malaysia (AIM) in the 1980s with the aim to assist the poor by improving their living standards. The AIM initiated various economic empowerment programs to support microenterprises. Inspired by the success story of Grameen Bank in Bangladesh, AIM started with a pioneer project in 1986 with 373 clients (known as "Sahabat" in Bahasa Malaysia or "good friend" in English). In due 
Thaker, Kassim, Amin, Salleh, Othman, \& Kassim $\mid$ Modeling the Demand for Islamic Microfinance Services: An Application of PLS-SEM Approach

course of time, Malaysian government has extended direct financial support which helped AIM to turned into an effective Islamic Microfinance Institution (IsMFI). The government used to allocate special fund for AIM in every budget, for instance, it has received a fund equivalent to RM2.7 billion in 2018. The main reason of allocating special funds to Microfinance Institutions (MFIs) is because of their outstanding contribution to the national economy.

Over the last few decades, AIM has experienced many reforms in terms of loan diversifications which has changed from subsidies to commercial financing. As of February 2015, AIM has sanctioned loans a total of RM 12.2 billion among 356,458 members from 135 different branches whereas this loan was only RM891,488 distributed among 3,220 members from 27 branches in 1990. It is also estimated that the total market share of AIM will reach to 50\% in 2018 from 40 percent in 2013 (Amanah Ikhtiar Malaysia, n.d.).

\subsection{Objectives}

Since the capital availability is a pre-condition for ensuring financial sustainability of microfinance clients, it is important to identify the factors affecting the demand for MFIs among the clients. This study aims to identify the key factors affecting the demand for Islamic microfinance (ISMF) among the women micro-entrepreneurs in Malaysia by surveying a total of 250 respondents from AIM, the largest ISMFI in Malaysia. The demand factors are categorized into four areas (4As), namely affordability, accessibility, adequacy and awareness. This study intended to identify the most significant factors from 4 As.

The remaining part of this paper is organized as follow: next section introduces background theory of microfinance with the finding of previous studies followed by methodology and data, analysis and the last section contain conclusions and recommendations.

\section{Literature Review}

\subsection{Background Theory}

Microfinance theory is based on the concept of changing the economic lifecycle of the poor who are excluded from formal financial services. The theory is tested by targeting the clients who are either absolute or hard-core poor. The gross monthly household income is measured based on the poverty line income (PLI) which is estimated based on the price of basic necessities. Households below the PLI are considered as "absolute poor" category, whereas households with income lower than half of the PLI are categorised as 
Thaker, Kassim, Amin, Salleh, Othman, \& Kassim $\mid$ Modeling the Demand for Islamic Microfinance Services: An Application of PLS-SEM Approach

"hardcore poor" category, where both categories are selected of credit assistance (Al-Mamun et al., 2011).

According to the Microfinance theory, poor clients become the members of a microfinance institution and obtain loan for income generating activities, inculcate saving behavior for the repayment of earlier loans and receive the subsequent loan for the extension of their small businesses to microenterprises. The theory describes life changing cycle of the poor who start the journey with small informal loan and end up as successful microentrepreneurs with the financial knowledge, business management and technical skills. This theory is proven as an effective tool to economically empower the poor in all most every part of the world.

The concept of Islamic Microfinance is developed by blending of microfinance theory and Islamic principles. Based on this, AIM was established in 1987 to enhance the economic status of the poor in Malaysia through micro-credit and later on extended to microfinance scheme. As of June 2017, AIM has extended its outreach to 23 states in Malaysia with a total of 136 branches and serving a total of 45,382 clients known as 'Sahabat' (Amanah Ikhtiar Malaysia, n.d.).

The core of microfinance theory is based on group lending without any collateral. The group responsibility acts as the social collateral which is proven successful in terms of loan repayment history. Likewise, AIM employs the group-based lending mechanism by offering collateral-free loans based on qard-hasan concept with a 10\% service charge. Other features of microfinance are the mandatory requirements of attending skills upgrading training and weekly meeting programs. Fresh applicants are required to take part a one-week training program so that they can gather information on the rules and regulations, IsMF schemes, and repayment schedules before receiving the loan as a Sahabat. Upon passing the certain evaluation criterion, groups of five Sahabats are formed and the groups are then assigned to particular center consisting of two to twelve groups per center (Amanah Ikhtiar Malaysia, n.d.). The responsible officers used to conduct review sessions during their weekly meeting on the loan performances as well as participation of Sahabats in other social services. of the Sahabats. The amount of loan can be varied depending on the microfinance schemes but loan repayment is scheduled on weekly basis.

A key to success of microfinance theory lies on the group-based lending mechanism to mitigate the risk of loan default. AlM's rule state that all the Sahabats are required to be in a group of five members which is intended to mitigate default risk. This works well as the group members would be vouching for one another throughout the loan disbursement process although it is considered as individual loans. In case of loan default within the group 
Thaker, Kassim, Amin, Salleh, Othman, \& Kassim $\mid$ Modeling the Demand for Islamic Microfinance Services: An Application of PLS-SEM Approach

members, the pooled funds are utilized to assist the defaulting members to repay their weekly loan instalment. Mason et al. (2015) advocate that the feeling of this peer pressure and accountability among the Sahabats turn into a mechanism of collective responsibility as reflected in the highest loan repayment rate (99.6\%).

In addition to the conventional microfinancing mechanism, AIM sets the objectives in such way that help enhancing the economic condition of the target groups. In this aspect, various benevolent financing schemes are offered: the basic financing scheme is i-Mesra scheme (up to RM 10,000) that aims to finance economic projects expected to generate income to the clients; the $i$-Srikandi scheme (up to RM 20,000) that is eligible for individuals with sustainable and successful projects; and the i-Wibawa scheme that is specifically designed for individuals taking i-Mesra or i-Srikandi scheme and providing soft loans to those who are in need of additional capital for the expansion of business to grab seasonal opportunities. AlM also offer noneconomic financing schemes such as the i-Bistari scheme (education loan), $i$ Sejahtera scheme (housing/multipurpose loan), i-Penyayang scheme (recovery loan for the defaulter) and the i-Emas scheme (loan for old people whose age are 75 years and above) (Mason et al., 2015).

Apart from the financing mechanism, AIM also gives stresses on the importance of acquiring their clients with appropriate entrepreneurship skill and financial knowledge to ensure that clients can manage their businesses efficiently. Some of the programs offered include business development, human capital development and training program. Additionally, AIM established the Charity and Welfare Fund for Sahabat (Tabung Kebajikan dan Kesejahteraan Sahabat) in 2006 to reduce their financial burden and mental distress during the emergency situations like chronic illnesses and hospitalisation, funeral ceremony, natural disasters and other calamities.

\subsection{Previous Studies}

The main purpose of this section is to review literatures that focus on the factors affecting the demand for microfinance product and services. Even though many studies are conducted on this area, limited studies are available that focuses on Islamic microfinance. Despite the fact, we attempt to review the existing literatures as the basis of theoretical underpinning of our structural model which to be empirically tested on the clients of AIM.

Over last two decades, the number of poor people receiving microcredit has increased substantially across the world. Many researchers have illustrated the key deriving factors of demands for microfinance and innovative strategies to improve its outreach to the Bottom of Pyramid (BOP). The BOP based on the model of Four A's introduced by C.K Prahalad and applied in the 
Thaker, Kassim, Amin, Salleh, Othman, \& Kassim $\mid$ Modeling the Demand for Islamic Microfinance Services: An Application of PLS-SEM Approach

area of international marketing (Kamande and Jarhult, 2013). These Four A's are Accessibility, Awareness, Affordability, and Availability (Prahalad, 2010). Sometimes the term Accessibility is replaced by Acceptability (Anderson and Billou, 2007). In our study, we have taken these 4As into account to identify different dimensions of demands factor of Islamic microfinance. We have considered the factor Adequacy instead of Availability.

According to Selos and Mair (2007), the 4As model is receiving rather lackluster recognition due to inadequate researches to validate its relevance, hence resulting in the lack of literature covering its application to cater for the BOP segment. London \& Hart (2011) highlight the importance of the 4As model to ensure the success of people in BOP segment. However, a proper theoretical framework on implementing the model has yet to be established.

The first concept of 4As model is 'Accessibility' which is achieved, according to Prahalad (2012), when consumers are located in remote and suburban areas with the accessibility of any products and services. In contrast to this, some areas have fragile infrastructures such as poor road conditions where transport of goods and services are extremely difficult particularly for trucks, trailers and lorries. Anderson and Billou (2007) view that most of the rural markets have the characteristics of poor infrastructures causing a disruption of normal supply chain and distribution channel. The same study also added that the opportunity of various markets i.e., capital, product and labor markets are mostly unavailable in the rural markets. To overcome this situation, it is suggested that the producers and local organizations can work on partnership basis within the BOP markets. It is also recommended to set up a close collaboration with local institutions, non-governmental organizations as well as local entrepreneurs so that all the parties involved in this chain can become a part of effective networking system in the BOP segment (Shah, 2012; Soete, 2010; Seelos \& Mair, 2007).

The second factor of 4As model is 'Awareness' that measures the extent of customers' level of awareness on particular products or services. Chikweche and Fletcher (2012) assert that creating awareness in the BOP segment pose a real challenge for the organizations because their target groups are usually selected from the people in low-income bracket and majority of them have neither access to mass media such as radio, television, internet nor to print media like newspapers. It is important to create 'Awareness' among the BOP consumers and producers. This helps consumers to make the best use of information and grab the optimal benefits from the products and services. This also supports producers to evaluate the market demands of their products. Pralahad (2012) emphasizes on the awareness creation program within BOP segment with the organizational support that designed for specific target group with diverse needs. 
Thaker, Kassim, Amin, Salleh, Othman, \& Kassim | Modeling the Demand for Islamic Microfinance Services: An Application of PLS-SEM Approach

The third factor of 4As model is 'Affordability' which is one of the most challenging factors for the BOP segment due to low-income status of consumers. More specifically, the organization must take into consideration of their products and services with their cash flows which they receive as incomes on a daily basis. Thus, the pricing strategy is identified as a key challenging factor in BOP segment (Anderson \& Billou (2007). Chikweche \& Fletcher (2012) claim that the researchers attempting to implement a welldeveloped market-price mechanism under any BOP segment have a very limited outcome.

The last factor of 4As model is 'Availability' which is measured by the time scale when the customers are able to own and utilize the products or services. It is observed that the BOP consumers would only purchase products when they have enough disposable income, and the product is readily available in the market. According to Prahalad (2011), an uninterrupted supply chain is key to gain trust and loyalty of customer at BOP segment.

In light of above literature review, we observed that most of the studies focus on the 4As model in determining the demand for products and services other than microfinance. In this study, we attempt to fill the gaps in existing literatures by analyzing the 4As model in determining the demand factors of Islamic Microfinance services in Malaysia.

A few factors have been taken into consideration as potential variables in building a conceptual framework for the research model. As shown in Figure 1 , the dependent variable for this conceptual framework is the demand for Islamic Microfinance (ISMF) and the independent variables that are identified as the factors affecting the demand for IsMF are accessibility, awareness, adequacy and affordability. These four variables described the products and services offered by AIM under their IsMF schemes.

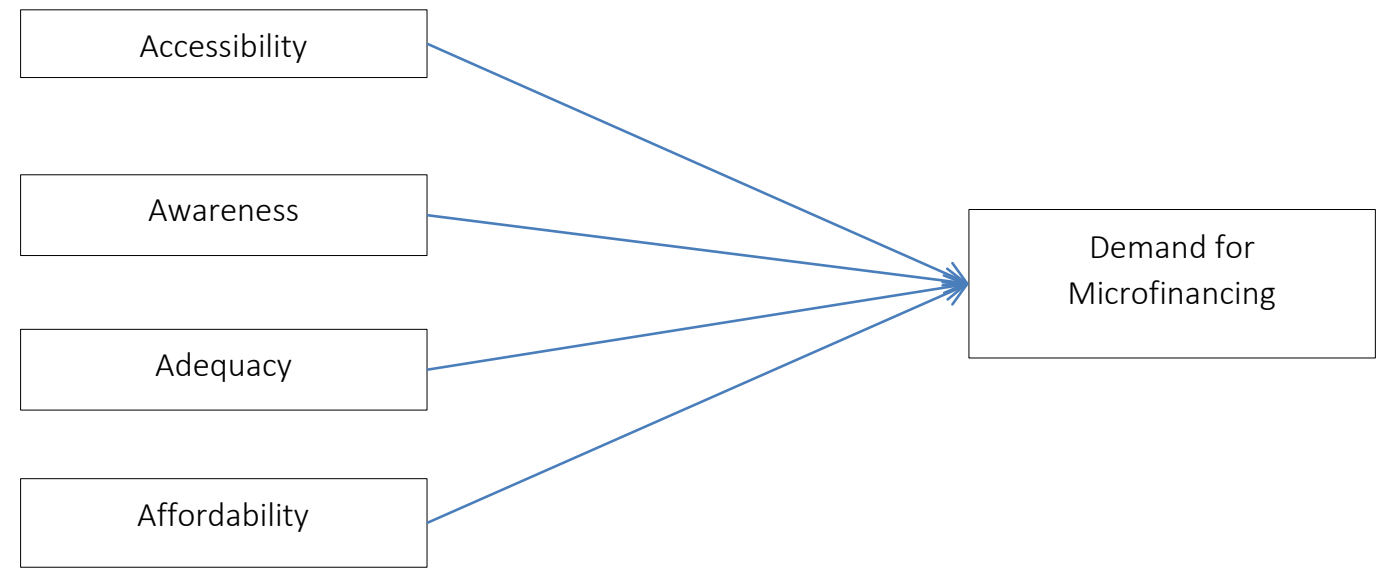

Figure 1. Research Framework

Source: Adopted \& Adapted from Prahalad (2010)

International Journal of Islamic Economics and Finance (IJIEF), 5(1), 89-106 | 95 
Thaker, Kassim, Amin, Salleh, Othman, \& Kassim $\mid$ Modeling the Demand for Islamic Microfinance Services: An Application of PLS-SEM Approach

\subsection{Hypothesis}

In line with the objective of this study, which is to identify the factors determining the demand for IsMF among women micro-entrepreneurs in Malaysia, the following hypotheses are constructed based on the $4 \mathrm{~A}$ model suggested by Prahalad (2009):

$\mathrm{H}_{1} \quad$ : Accessibility has positive relationship in affecting the demand for ISMF

$\mathrm{H}_{2} \quad$ : Awareness has positive relationship in affecting the demand for IsMF

$\mathrm{H}_{3} \quad$ : Adequacy has positive relationship in affecting the demand for ISMF

$\mathrm{H}_{4}$ : Affordability has positive relationship in affecting the demand for ISMF

\section{Methodology}

\subsection{Data Collection Procedure and Sample}

In this study, we have collected data directly from the field survey. We distributed structured questionnaires to the clients of Amanah Ikhtiar Malaysia (AIM), Hulu Selangor branch. Purposive sampling has used to gather the data from the client of AIM. The total of 402 questionnaires were distributed and only a total of 250 used for data analysis. It happened due to missing or incompleteness of data during the process of data cleaning and recoding.

\subsection{Model Development}

The data are analyzed by using SPSS Statistics version 25.0 and SmartPLS version 3.2.7. This study adopted Partial Least Square (PLS) method because its' its ability to measure causal relationships among all the latent constructs simultaneously and ability to focus on structural model for dealing with measurement errors (Farooq, 2016; Hair et al., 2017). Since this study is explanatory in nature, the application of PLS model show the best fit indices for the current study (Hair et al., 2017). As suggested by Hair et al. (2017), measurement models are examined separately before evaluating the structural model. Before conducting measurement models, we much ensure that there is no common method bias which indicates a certain context where data for dependent and independent variables are gathered from the same respondents using the same instruments. For this purpose, the current study employs Harman (1976) one factor test. In conducting the one-factor test, the researchers observed the guidelines and approaches suggested by Podsakoff et al. (2003). All the items of measurement scale are entered into a principal component analysis with varimax rotation, so that any signs of single factor can be identified from factor analysis. Based on the finding, it showed that the 
Thaker, Kassim, Amin, Salleh, Othman, \& Kassim $\mid$ Modeling the Demand for Islamic Microfinance Services: An Application of PLS-SEM Approach

first factor accounted for $40.42 \%$ of variance. This figure meets the threshold level which is less than 50 percent suggested by Podsakoff et al. (2003).

\subsubsection{Research Instruments}

This paper computed the demographic question using a nominal scale as suggested by Haque and Raihan (2004) and Amin et al. (2007). This nominal scale provides a range of values for obtaining the age of respondents. The choice of the answers or items under each construct was based on a five-point Likert type scale, ranking as 1 (strongly disagree), 2 (disagree), 3 (neutral), 4 (agree), 5 (strongly agree), which is suggested by Bhatti (2007) and Amin et al. (2007). Using a Likert type scale, the respondents choose a point on the scale reflecting his or her position towards the statement. Extant literatures have been used to extract the constructs and the items. All the constructs and items are adopted and adapted to serve the purpose of this study. All major scale items are adapted from Riquelme \& Rios (2010) where each construct consists (several items) i.e., adequacy (five items), affordability (six items), awareness (ten 10 items), accessibility (nine items), and demand for Islamic microfinance (eight items).

\section{Results and Analysis}

\subsection{Descriptive Statistics}

We have collected the data from AIM clients to determine the factors affecting the demand for ISMF services. As shown in Table 1, most of the respondents were female (51.6\%) and followed by male (48.4\%). Almost many of them were fall under the age category of 40 and below (85.2\%) with the dominance of married micro-entrepreneurs (59.2\%), while most of them (84\%) have an average of more than 3 family members. It is also important to know the educational qualification of respondents because it plays a key role in making the economic decision. Thereby, majority of the respondents (81.6\%) have diploma and degree level educational qualification. This indicates that AIM's clients are capable of enhancing their financial literacy by attending various training programs. This factor is also very much related to their average incomes.

Table 1 also demonstrates the respondents' average monthly income. The respondents were asked about their monthly average income over the last one year and a quarter of (24.4\%) and one-fifth of them (19.6\%) have monthly average income less than RM 1000 and more than RM 5000, respectively. Apart from these two income levels, less the half of the respondents (43\%) 
Thaker, Kassim, Amin, Salleh, Othman, \& Kassim $\mid$ Modeling the Demand for Islamic Microfinance Services: An Application of PLS-SEM Approach

have achieved monthly average income with a range between RM 2000-RM

5000. This higher income pattern of the respondents strongly suggests the effectiveness of Islamic microfinance program offered by AIM.

Table 1. Descriptive Statistics of the Respondents

\begin{tabular}{llrr}
\hline \multicolumn{1}{c}{$\begin{array}{c}\text { Demographic } \\
\text { Factors }\end{array}$} & \multicolumn{1}{c}{ Category } & Frequency & Percent \\
\hline Gender & Male & 121 & 48.4 \\
Age & Female & 129 & 51.6 \\
& $20-30$ & 148 & 59.2 \\
& $31-40$ & 65 & 26.0 \\
Marital Status & $41-50$ & 31 & 12.4 \\
\multirow{4}{*}{ Education } & more than 50 & 6 & 2.4 \\
& Single & 148 & 59.2 \\
& Married & 102 & 40.8 \\
& No Education & 1 & .4 \\
Family Size & Secondary (SPM) & 29 & 11.6 \\
Monthly Income & Diploma & 36 & 14.4 \\
& Degree & 168 & 67.2 \\
& Postgraduate (Master/PhD) & 16 & 6.4 \\
& 1-3 & 40 & 16.0 \\
& More than 3 & 210 & 84.0 \\
& Less than RM1000 & 61 & 24.4 \\
& RM1001-RM2000 & 32 & 12.8 \\
& RM2001-RM3000 & 35 & 14.0 \\
& RM3001-RM4000 & 40 & 16.0 \\
& RM4001-RM5000 & 33 & 13.2 \\
& More Than RM5000 & 49 & 19.6 \\
\hline
\end{tabular}

\subsection{Measurement Model}

The convergent validity is tested at the initial stage. During the test of convergent validity, indicator or items loadings, average variance extracted (AVE) and composite reliability (CR) are taken into the consideration. Based on the results presented in Table 2, items' loading exceeded 0.6 for items, which meet the recommended value suggested by Hair et al., (2009). The threshold value of AVE is at least 0.50 as recommended by Hair et al., (2009) and we obtain the values of AVE within a range of 0.547 and 0.706 and CR value ranged from 0.854 to 0.936 which meet the recommended value of 0.7 . Table 2 shows the results of measurement model with the values of individual item loading, AVE and CR.

After conducting the test of convergent validity, the next stage is to test the discriminant validity. Because of certain limitations of conducting test for discriminant validity under the Fornell-Larcker (1981) criterion, Henseler et 
Thaker, Kassim, Amin, Salleh, Othman, \& Kassim | Modeling the Demand for Islamic Microfinance Services: An Application of PLS-SEM Approach

al., (2015) have suggested an alternative approach to evaluate discriminant validity by using heterotrait-monotrait ratio of correlations. Henseler et al. (2015) also demonstrate the superior performance of this method with the support of Monte Carlo simulation study. We have adopted this approach to test the discriminant validity as shown in Table 3. If the HTMT value is greater than $\mathrm{HTMT}_{0.85}$ value of 0.85 (Kline 2011), or HTMT 0.90 value of 0.90 (Gold et al., 2001), then there is a problem of discriminant validity. In our obtained result, all the values passed the criterion of HTMT0.90 (Gold et al., 2001) and the HTMT $_{0.85}$ (Kline, 2011) as shown in Table 3 which indicates that discriminant validity has been ascertained. Based on these results, it indicates that measurement model has adequate convergent validity and discriminant validity.

Table 2. Results of Measurement Model

\begin{tabular}{|c|c|c|c|c|}
\hline Construct & Items & Loadings & AVE & $C R$ \\
\hline \multirow[t]{6}{*}{ Affordability } & CD1 & 0.888 & 0.682 & 0.928 \\
\hline & CD2 & 0.888 & & \\
\hline & CD3 & 0.823 & & \\
\hline & CD4 & 0.815 & & \\
\hline & CD5 & 0.782 & & \\
\hline & CD6 & 0.749 & & \\
\hline \multirow[t]{9}{*}{ Awareness } & CB1 & 0.800 & 0.619 & 0.936 \\
\hline & CB2 & 0.815 & & \\
\hline & CB3 & 0.768 & & \\
\hline & CB4 & 0.769 & & \\
\hline & CB5 & 0.805 & & \\
\hline & CB6 & 0.816 & & \\
\hline & CB7 & 0.763 & & \\
\hline & CB8 & 0.778 & & \\
\hline & CB9 & 0.764 & & \\
\hline \multirow[t]{8}{*}{ Accessibility } & CA2 & 0.622 & 0.547 & 0.905 \\
\hline & CA3 & 0.734 & & \\
\hline & CA4 & 0.832 & & \\
\hline & CA5 & 0.739 & & \\
\hline & CA6 & 0.674 & & \\
\hline & CA7 & 0.751 & & \\
\hline & CA8 & 0.787 & & \\
\hline & CA9 & 0.755 & & \\
\hline \multirow[t]{5}{*}{ Adequacy } & CC1 & 0.766 & 0.706 & 0.923 \\
\hline & $\mathrm{CC} 2$ & 0.807 & & \\
\hline & $\mathrm{CC} 3$ & 0.86 & & \\
\hline & $\mathrm{CC} 4$ & 0.874 & & \\
\hline & $\mathrm{CC} 5$ & 0.888 & & \\
\hline \multirow[t]{4}{*}{ Demand } & B1 & 0.638 & 0.596 & 0.854 \\
\hline & B6 & 0.834 & & \\
\hline & B7 & 0.821 & & \\
\hline & B8 & 0.779 & & \\
\hline
\end{tabular}

Note: B3, B4, B2, B5, CA1 and CB10 were deleted due to low loadings. 
Thaker, Kassim, Amin, Salleh, Othman, \& Kassim $\mid$ Modeling the Demand for Islamic Microfinance Services: An Application of PLS-SEM Approach

Table 3. HTMT Criterion

\begin{tabular}{lllll}
\hline & Accessibility & Adequacy & Affordability & Awareness \\
\hline Accessibility & & & & \\
Adequacy & 0.693 & & & \\
Affordability & 0.661 & 0.804 & & \\
Awareness & 0.762 & 0.845 & 0.783 & \\
Demand & 0.695 & 0.551 & 0.591 & 0.662 \\
\hline
\end{tabular}

\subsection{Structural Model}

Ramayah et al. (2016) have suggested using $R^{2}$ to observe the goodness of the structural model. According to Hair et al. (2011), coefficient of determination and the level of significance of the path coefficients (beta values) can be captured by $R^{2}$. The $R^{2}$ for the current research is 0.42 , suggesting that $42 \%$ of the variance of demand for Islamic Microfinance can be explained by accessibility, adequacy, affordability, and awareness.

Subsequently, in order to assess the statistical significance of path coefficients, the current study has calculated the path coefficients of the structural model and performed bootstrap analysis (re-sampling $=500$ ). The results presented in table 3 reveal that accessibility $(b=0.37, p<0.01$ ), affordability $(b=0.188, p<0.01)$ and awareness $(b=0.24, p<0.01)$ have $a$ positive and significant relationship with the demand for Islamic Microfinance. Thus, the hypotheses of $\mathrm{H} 1, \mathrm{H} 3$ and $\mathrm{H} 4$ are supported. In addition, the results of structural model also indicated that adequacy factor is found to be insignificant. Thus, $\mathrm{H} 2$ is not supported.

Table 4. Results of Structural Model

\begin{tabular}{llllll}
\hline Hypothesis & R/ship & Std. Beta & Std. error & t-value & Decision \\
\hline H1 & ACC -> DD & 0.37 & 0.094 & 3.944 & Supported \\
H2 & ADEQ -> DD & -0.078 & 0.113 & 0.697 & Not supported \\
H3 & AFFORD -> DD & 0.188 & 0.097 & 1.932 & Supported \\
H4 & AWARE -> DD & 0.24 & 0.115 & 2.085 & Supported \\
\hline
\end{tabular}

\subsection{Importance-Performance Map Analysis}

In order the confirm the obtained results, we have conducted ImportancePerformance Map Analysis (IPMA) as suggested by Ringle and Sarstedt (2016). The main advantage of IPMA is that it can identify predecessors which have a relatively low performance but high importance for the target constructs. IPMA becomes a very useful analytical tool in PLS-SEM. IPMA graphically extends the standard path coefficient estimates in more practical way (Ringle \& Sarstedt, 2016). 
Thaker, Kassim, Amin, Salleh, Othman, \& Kassim $\mid$ Modeling the Demand for Islamic Microfinance Services: An Application of PLS-SEM Approach

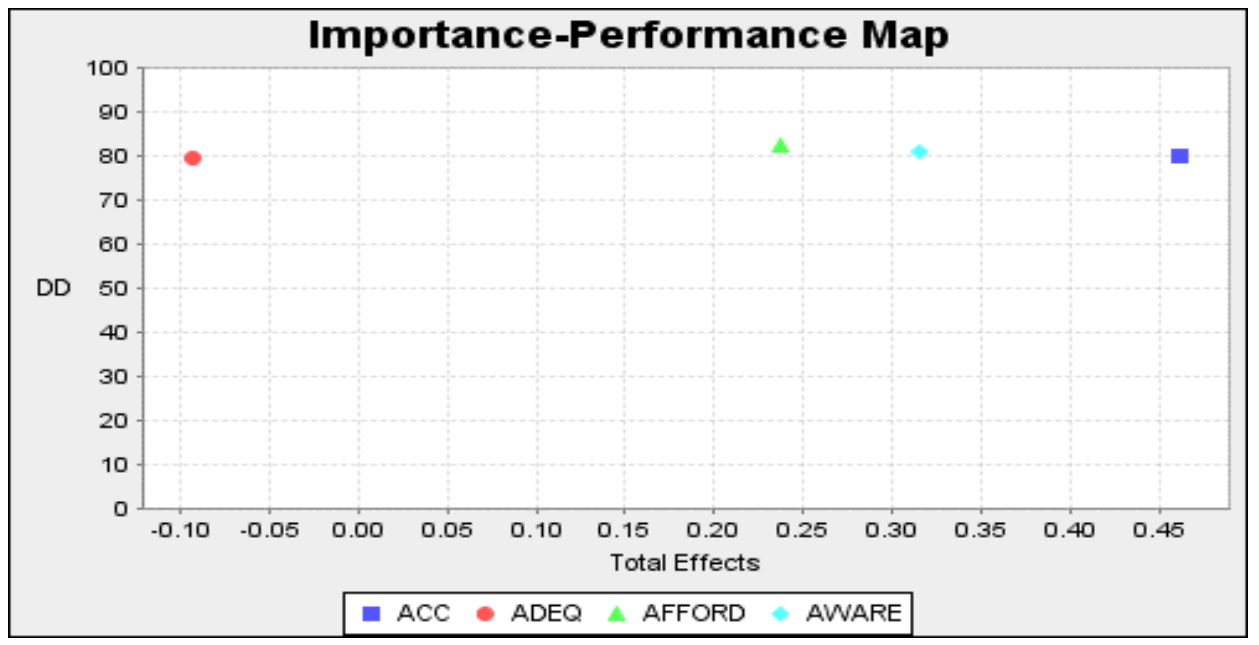

Figure 2. Importance-Performance Map Analysis

This paper applied Importance-Performance Map Analysis (IPMA) in order to evaluate the most influencing factors as represented by four predecessors (accessibility, adequacy, affordability and awareness) affecting the demand for Islamic Microfinance (Figure 1). The IPMA's results is presented in table 4 which reveals that the construct Adequacy has higher value in performance index but not under importance index in predicting the demand for Islamic Microfinance. This paper found the higher weights of three other constructs i.e., accessibility, affordability and awareness whereas affordability factor remains in the highest performance domain followed by awareness and affordability.

Table 5. Importance-Performance Map Analysis Statistics

\begin{tabular}{lcc}
\hline \multicolumn{1}{c}{ Construct } & Importance (Total Effect) & Performance (Index Values) \\
\hline Accessibility & 0.461 & 79.896 \\
Adequacy & -0.093 & 79.461 \\
Affordability & 0.237 & 82.377 \\
Awareness & 0.316 & 81.042 \\
\hline
\end{tabular}

In this study, it shows that certain factors are important that can ensure the higher demand for Islamic Microfinance. The key items under the accessibility factors that have greater influence on Islamic Microfinance products and services are: i) the distances of AIM's branches which is related to higher borrowing cost, ii) the loan size is relatively small in amount that the borrowers' have to incur a higher cost to access the loan, iii) collateral requirements, guarantor requirement, and repayment method which are found to be highly important, iv) efficiency of Islamic Microfinance service provides like AIM provided by the microfinance providers, v) continuous advise and consultation, and vi) easy and simple loan application procedures and process. 
Thaker, Kassim, Amin, Salleh, Othman, \& Kassim $\mid$ Modeling the Demand for Islamic Microfinance Services: An Application of PLS-SEM Approach

The loan size is important for the clients regardless of their status as fresh or old members. Most of the members are either involved in micro-enterprises or planning to start new ventures which requires adequate amount of capital. That is why the members of AIM consider this item as one of the top priority items affecting their demand for Islamic Microfinance (IsMF). Moreover, the cost of borrowing becomes higher if we consider the opportunity cost of access to IsMF. Sometimes, the borrowers need to attend various meeting and maintain other loan procedures which require them to visit the branches frequently and in most cases they have to spend time, money and give up some other works, which are considered as the opportunity cost. This higher borrowing cost demotivate them to apply for IsMF. Moreover, the repayment method is important for the borrowers. This is vital because not all the borrowers have same type of businesses and they have different cash-flows. Thus, the identical or standard loan repayment schedule for all the borrowers regardless of their business types cannot be justified. Other aspects that affect the demand for IsMF are the product services including the efficiency of staffs, rules, regulations and procedure of loan approval. Sometimes, ISMF institution like AIM become very rigid on their loan approval procedures. The borrowers who are in urgent need for IsMF must follow the same procedures as regular borrowers, and this whole cumbersome loan approval procedures in some cases demotivate borrowers to stick to the IsMF. It is also important to increase the efficiency of IsMF product and services. This efficiency leads to retain and attract new members which is cost effective for the institution and also beneficial for the borrowers.

\section{Conclusion and Recommendation}

\subsection{Conclusion}

The aim of this study is to identify factors determining the demand for Islamic microfinance (ISMF) among women micro-entrepreneurs in Malaysia. This study has conducted a survey with the clients of Amanah Ikhtiar Malaysia in Selangor. This study adopts the Partial Least Squares (PLS) method in detecting the potential demand factors of ISMF, namely affordability, accessibility, adequacy and awareness. The results show that only "accessibility" factor has significant and positive relationship with the demand for IsMF. More specifically, a few measurements items under accessibility such as, distance to microfinance institution, collateral requirements, guarantor requirement, application procedure and process, repayment method, efficiency of services by microfinance providers, continuous advice and consultation, and number of microfinance centers which are significantly affecting the demand for ISMF in Malaysia. It shows that for the clients of 
Thaker, Kassim, Amin, Salleh, Othman, \& Kassim $\mid$ Modeling the Demand for Islamic Microfinance Services: An Application of PLS-SEM Approach

microfinance, easier accessible and convenience accessible would encourage them to use continuously the services that offered by microfinance institutions. At the same time, IsMF institutions can increase their marketing know-how by implementing effective accessibility strategies that generate services availability to the clients.

Based on the analysis of Importance-Performance Map Analysis (IPMA), it shows that IsMF institutions should not focus much on adequacy as it will possibly reduce the profit of the institution. The three other constructs which are more important are accessibility, affordability and awareness. Affordability is already high in performance but awareness is slightly lower, so the microfinance institutions should focus on enhancing affordability matter. In terms of accessibility, it is important for IsMF institution to simplify the application and approval process to obtain IsMF.

\subsection{Recommendation}

In view of above findings, this paper recommends certain aspects of products and services of AIM. The ISMF institutions like AIM need to focus on accessibility factors to ensure that the microfinance product is appealing to the clients. The sufficient number of IMF services centres should be established along with the reduction of the cost of IsMF products and services. Similarly, IsMF providers should also take into account of its product's features including collateral requirements, guarantor requirement, and repayment method which are highly valued by the clients in determining the demand for IsMF. the IsMF providers need to ensure that these requirements are not set at highest stringent level. We also suggest that IsMF providers may adopt innovative risk mitigations mechanism by refining the group lending and weekly repayment methods. This study also suggest that MFIs should continue to strive in providing better services to ensure customers retention as well as attraction of new clients for their services. It is expected that adopting the above recommendations can enhance the participation of women in microenterprises and uplift them toward higher economic living standards in Malaysia.

\section{Acknowledgement}

This paper originates from of a research project approved in 2015 funded by the Ministry of Higher Education (MOHE) Malaysia under the Fundamental Research Grant Scheme (Project ID: FRGS15-230-0471). The authors would like to thank MOHE Malaysia for generously funding this research project. 
Thaker, Kassim, Amin, Salleh, Othman, \& Kassim | Modeling the Demand for Islamic Microfinance Services: An Application of PLS-SEM Approach

\section{References}

Amanah Ikhtiar Malaysia. (n.d.). Retrieved from http://www.aim.gov.my

Al Mamun, A. (2011). Impact of Amanah Ikhtiar Malaysia's schemes on hardcore poor households in Peninsular Malaysia. (Doctoral Thesis). Faculty of Management, Multimedia University, Malaysia.

Amin, H., Baba, R. and Muhammad, M. Z. (2007). An analysis of mobile banking acceptance by Malaysian customers. Sunway Academic Journal, 4, 1-12.

Anderson, J. and Billou, N. (2007). Serving the world's poor: innovation at the base of the Economic pyramid, Journal of Business Strategy, 28 (2), 14-21.

Bhatti, T. (2007). Exploring factors influencing the adoption of mobile commerce. Journal of Internet Banking \& Commerce, 12(3), 1-14.

Chikweche, T. and Fletcher R. (2012). Revisiting the marketing mix at the bottom of Pyramid (BOP): From theoretical considerations to practical implications, Journal of Consumer Marketing, 29(7),507-520.

Fornell, C., and Larcker, D. F. (1981). Evaluating structural equation models with unobservable variables and measurement error. J. Mark. Res. 18, 39-50.

Gertler, P., Levine, D.I., Moreti, E. (2003). Do microfinance programs help families iinsure consumption against illness? (Working Paper series C03-129) Center for International Development Economics Research (CIDER), University of California, Berkeley.

Gold, A. H., Malhotra, A., \& Segars, A. H. (2001). Knowledge management: An organizational capabilities perspective. Journal of Management Information Systems, 18(1), 185-214.

Hair, J. F., Black, W. C., Babin, B. J., \& Anderson, R. E. (2009). Multivariate data analysis. Upper Saddle River, NJ: Prentice Hall.

Hair, J. F., Ringle, C. M., \& Sarstedt, M. (2011). PLS-SEM: Indeed a silver bullet. Journal of Marketing Theory and Practice, 19(2), 139-151.

Harman, H.H. (1976), Modern Factor Analysis, Chicago: University of Chicago Press.

Henseler, J., Ringle, C.M. and Sarstedt, M. (2015). A new criterion for assessing discriminant validity in variance-based structural equation modeling. Journal of the Academy of Marketing Science, 43(1), 115-135.

Kamande, S., \& Jarhult, W. (2013). Reaching the mass market of the base of the pyramid-using the five A's concept. (Master Thesis). Linnaeus University, Sweden. 
Thaker, Kassim, Amin, Salleh, Othman, \& Kassim | Modeling the Demand for Islamic Microfinance Services: An Application of PLS-SEM Approach

Khandker, S. (2003). Micro finance and poverty: Evidence using panel data from Bangladesh. (Research Paper series 2945), World Bank Policy. World Bank. Washington.

Kline, R. B. (2011). Principles and practice of structural equation modeling. New York: Guilford Press.

London, T. and Hart, S. (2011). Next-generation business strategies for the base of the pyramid: New approaches for building mutual value, in a. upper saddle river (Eds.), Financial Times Press.

Mason, D. J., Jones, D. A., Roy, C., Sullivan, C. G., \& Wood, L. J. (2015). Commonalities of nurse-designed models of health care. Nursing Outlook, 63(5), 540-553.

Park, A. and Ren, C. (2001). Microfinance with Chinese characteristics. World Development, 29(1), 39-62.

Podsakoff, P. M., MacKenzie, S. B., Lee, J. Y. and Podsakoff, N. P. (2003). Common method biases in behavioral research: A critical review of the literature and recommended remedies. The Journal of Applied Psychology, 88(5), 879.

Prahalad C. K. (2009) The fortune at the bottom of the pyramid: Eradicating poverty through profits. Pearson Education Publishers, United States. 358

Prahalad, C. K. (2010). The fortune at the bottom of the pyramid: Eradicating poverty through profits. Revised and updated 5th anniversary. New Jersey (Eds.), Pearson Education.

Prahalad, C. K. (2012). Bottom of the pyramid as a source of breakthrough innovations. Product Development \& Management Association, 29(1), 6-12.

Prahalad, C.K. (2011). The fortune at the bottom of the pyramid: Eradicating poverty through profits, Revised and Updated 5th Anniversary. New Jersey (Eds.), Prentice Hall.

Ramayah, T., Cheah, J., Chuah, F., Ting, H., \& Memon, M. A. (2016). Partial least squares structural equation modeling (PLS-SEM) using SmartPLS 3.0: An updated and practical guide to statistical analysis. Singapore: Pearson.

Ringle, C. M. and Sarstedt, M. (2016). gain more insight from your pls-sem results: The importance-performance map analysis. Industrial Management \& Data Systems, 116(9), 1865-1886.

Riquelme, H. E. and Rios, R. E. (2010). The moderating effect of gender in the adoption of mobile banking. The International Journal of Bank Marketing, 28, 328-341. 
Thaker, Kassim, Amin, Salleh, Othman, \& Kassim $\mid$ Modeling the Demand for Islamic Microfinance Services: An Application of PLS-SEM Approach

Seelos, C. and Mair, J. (2007). Profitable business model and market creation in the context of deep poverty: A strategic view, Academy of Management Perspectives, 21(4), 49-63.

Shah, Ali M. (2012). Business strategies in the emerging markets. Journal of Asia-Pacific Business, 13, 4-15.

Soete, L. 2010. From science and technology to innovation for development. African Technology Development Forum Journal, 7(3/4), 9-14. 